\title{
Attitudes Towards Strangers: a test of Uslaner's Theory of Generalized Trust
}

\author{
Alfonso Serrano-Maillo \\ Universidad Nacional de Educación a Distancia \\ aserranom@der.uned.es
}

\begin{abstract}
Uslaner and others predict that generalized trust is an independent construct that does not need to be analyzed solely as an element of social capital. Uslaner's theory suggests that generalized trust should be measured with a single item about whether most people can be trusted or you can't be too careful. It is predicted that generalized trust is a predictor of attitudes towards strangers. Uslaner's theory conjectures that generalized trust is established early in life and that it does not depend on experience, and that variables that do not depend on experience will be better predictors of attitudes towards strangers than those that are influenced by experience. We explore hypotheses derived from Uslaner's theory of generalized trust with data from Spain collected in the frame of the 7th wave of the European Social Survey. Data analyses rely on standard regression tools.
\end{abstract}

Keywords: Uslaner's theory, Generalized trust, Attitudes towards refugees, Racist values.

Resumen: Uslaner y otros predicen que la confianza generalizada es un constructo independiente que no precisa ser analizado únicamente como un elemento del capital social. La teoría de Uslaner sugiere que la confianza generalizada debería medirse con un ítem único sobre si puedes confiar en la mayoría de las personas o si es mejor ser precavido. Se predice que la confianza generalizada es un predictor de las actitudes hacia los extraños. La teoría de Uslaner conjetura que la confianza generalizada queda establecida pronto en la vida de las personas y que no depende de la experiencia, así como que las variables que no dependen de la experiencia serán mejores predictores de las actitudes hacia los extraños que las que se encuentran influenciadas por la experiencia. Exploramos hipótesis derivadas de la teoría de la confianza generalizada de Uslaner con datos de España recogidos en el marco de la 7. oleada de la Encuesta Social Europea. Los análisis utilizan herramientas de regresión comunes.

Palabras clave: Teoría de Uslaner, Confianza generalizada, Actitudes hacia los refugiados, Valores racistas. 


\section{USLANER'S THEORY OF GENERALIZED TRUST}

Trust in strangers has been considered by many as an element or dimension of social capital (Economidou et al., 2017; Herreros and Criado, 2009). Putnam includes social trust as a component of a comprehensive social capital index with fourteen indicators. He finds that the agreement with the item «Most people can be trusted» is strongly correlated with the social capital index $(\mathrm{r}=0,92)$ in his aggregated data at the level of the nation (2001). At the same time, social capital is conjectured to influence attitudes towards others, including minority groups, because those high in social capital are expected to be more tolerant. Putnam defines social capital as the set of «features of social organization such as networks, norms, and social trust that facilitate coordination and cooperation for mutual benefit» (Putnam, 1995: 67). Though social capital may have a dark side, it is expected to allow individuals to solve problems more easily and widen the «awareness of the many ways in which our fates are linked» (Putnam, 2001: 288).

In contrast to the conception of trust in strangers as a component of social capital, Uslaner argues that trust in strangers is an important theoretical construct in itself and that it has a direct impact on attitudes towards others, including minorities. According to this author, there are two main kinds of trust: moralistic and strategic trust. What is characteristic of individuals high in moralistic trust is that they trust people who they do not know and who are different from them without expecting anything in return. Moralistic trust is formed early in life during the socialization process in the family and is stable thereafter, i.e. it does not change with experience. Uslaner observes a moral element in this kind of trust because there is a duty to treat others as you want to be treated and because it plays an essential role in community building and maintaining. On the other hand, strategic trust depends on the expectation of someone acting in a certain way, for example returning a favour. This variety of trust depends on experience, is highly mutable and is usually related to people we know or, at least, that are like ourselves. From these two varieties of trust, Uslaner (2002) makes the crucial distinction between trust that depends on experience and trust that does not. He refers to the first as generalized trust or trust on strangers or people different from us; and to the second as particularized trust or trust on people we know or that are like us. Institutional trust or trust on the Government and other institutions is also a type of experience-dependent trust, and there is evidence of a relationship between trust in institutions and attitudes towards immigration (Halapuu et al., 2013: 575-577).

Uslaner (2002) has made a connection between generalized trust and attitudes towards immigrants too: «People with faith in others are also supportive of immigrants 
[...] don't see illegal immigrants taking jobs from natives. And they have far more favourable views of legal immigrants than mistrusters» (2002: 196). Previous studies have found a relationship between trust understood as trust in strangers and attitudes towards immigration, with more trusting individuals holding more positive attitudes (Herreros and Criado, 2009; Economidou et al., 2017).

Two substantive hypotheses can be derived from Uslaner's theory and in relation to attitudes towards others:

$\mathrm{H}_{1}$. Generalized trust predicts attitudes towards refugees. Those high in generalized trust show more positive attitudes towards refugees.

$\mathrm{H}_{2}$. Variables that depend on experience predict attitudes towards refugees better than their experience influenced counterparts.

\section{REFUGEES AS STRANGERS IN CONTEMPORARY SPAIN}

There is evidence of an increase in xenophobic attitudes in Europe in connection to the large number of arrivals of immigrants, especially when coupled with the ongoing economic and financial crisis (Raines et al., 2017). The European Commission against Racism and Intolerance (ECRI) pointed out in its 2015 Annual Report that «refugees, asylum seekers and other migrants entering Europe [...] often face a grim reception, characterised by detention, insufficient social assistance and a hostile public opinion in most European countries» (ECRI, 2015: 10-11, 13-14).

But the concept of immigrant lacks specificity (Serrano-Maillo et al., 2008). Both football stars and asylum seekers are immigrants and it is unlikely that they evoke the same attitudes in the general population. In fact, significant differences in attitudes towards groups of immigrants have been found in empirical studies (Ford, 2011; Heath and Richards, 2016; Raines et al., 2017). It can be argued that undocumented refugees present certain particularities as a group of immigrants.

There exists a growing body of research on determinants of attitudes towards immigration, though most studies have concentrated on the systemic level of analysis. For example, there is evidence connecting authoritarian and ethnocentric values (Hainmuller and Hiscox, 2010; Ford, 2011), economic insecurity (Burns and Gimpel, 2000), perceived threats to national identity (Kaufmann and Harris, 2005) and political conservatism (Economidou et al., 2017) on one hand and more negative attitudes towards immigrants on the other. In particular, explanations of attitudes towards immigrants based on trust are usually contrasted in the literature with those with an economic base such as 
economic insecurity, political economy or fiscal burden theories (Hainmueller and Hopkins, 2014), or group threat theory (Blalock, 1967; Quillian, 1995). Tests of the economic dimension of group threat theory at the individual level have relied on subjective concerns about the financial situation at the personal or national level (Salamonska, 2016). Intergroup contact theory has been as well used to explain attitudes towards immigrants as members of an out-group (Allport, 1979), with recent studies supporting this hypothesis (Andreescu, 2011; McLaren 2003; Valentova and Berzosa, 2012). Again, we can assume that this factor depends on experience. Finally, many authors suggest that many Europeans believe that immigration is associated with more crime (Meuleman et al., 2016), though empirical evidence does not support this relationship at the objective level (Serrano-Maillo et al., 2008).

\section{METHODS}

\subsection{Sample}

To test our hypothesis about the relationship between generalized trust and attitudes towards refugees in Spain we will use data from the seventh wave of the European Social Survey (ESS 2014) ${ }^{1}$. The ESS follows a cross-sectional design using probability samples and has been conducted biannually in Europe since 2002. Its universe is composed by all people aged 15 and over. The ESS is administered face-to-face in the respondent's home by trained interviewers following a standardised approach and with the assistance of computers (CAPI). Minimum effective sample size in each country is 1500. The ESS is an academically driven survey, its quality is considered high according to international standards, and is widely used for social research.

\subsection{Measurement}

The ESS questionnaire allowed the estimation of the variables of interest involved in our hypotheses. It is customary to use survey data to test individual level conjectures (Thornberry and Krohn, 2000). I will describe the dependent, independent and control variables, as well as the theoretical rationale for their inclusion in the study.

\footnotetext{
${ }^{1}$ Data for the eight wave had not yet been released for Spain when this paper was written.
} 
Attitudes towards refugees. The ESS questionnaire includes in its seventh wave some items regarding attitudes towards immigrants. But, as we have seen, refugees are just one type of immigrants and it is too vague. Participants were asked about whether the Government should be generous judging applications for refugee status. Substantive answers were «Disagree strongly», «Disagree», «Neither agree nor disagree», «Agree» and «Agree strongly». Answers were recoded so that higher values mean opinions more favourable to Government being generous judging applications for refugee status.

Most people can be trusted. Three items in the ESS inquiry about whether most people can be trusted, try to take advantage of you, and are helpful might be related to trust. Using all three items is consistent with a usual strategy to reduce measurement error in the frame of classical test theory and with criticisms towards the first of the items when used in isolation (Crepaz et al., 2014; Reeskens and Hooghe, 2008). Uslaner, though, makes the strong point that the «most people can be trusted» single item (Rosenberg 1956: 690) is the only valid one to measure generalized trust and that research should be confined to it (Uslaner, 2002: 68-74). We will follow his advice in this paper.

Following Uslaner (2002), our nuclear independent variable is estimated with the single item about whether most people can be trusted or you can't be too careful. Participants could answer using a 11-point ordinal scale from «You can't be too careful» to «Most people can be trusted». Higher values represent higher degrees of trust.

Institutional trust. A battery of seven items about the degree of interviewees' trust in the country's parliament, in the legal system, in politicians, in the European Parliament, in the United Nations and in the police, again answerable with an 11-points scale, was subjected to a principal components analysis that favoured a one-factor solution. Higher values represent higher degrees of institutional trust. With the exception of institutional trust, the rest of independent variables and controls showed in this paper are based on single items.

$T V$ watching and $T V$ news. Two items question about the time per week spent on average watching television, one referring to total time and the other to news, politics or current affairs. In both cases, a card with eight categories of response from «none» to «more than 3 hours» was shown to the respondents for them to answer. Higher values mean longer exposition to TV in general and to TV news in particular.

People with whom you can discuss and how often socially meet. Two items in the ESS questionnaire ask about the number of persons with whom the respondent can discuss intimate and personal matters and how often the respondent socially meets with friends, relatives or colleagues. It can be argued that both issues are related to the interviewee's degree of trust in people he or she knows, i.e. individuals that are known to and 
similar to the respondent. Both questions allow seven substantive responses from «none» to «10 or more» and from «never» to «every day». Higher values mean more people to discuss with and more frequent social meetings.

Victimization and fear of crime. Both variables are measured with questions that are usual in Criminology: whether the respondent o a member of his/her household has suffered a robbery or an aggression in the last five years; and whether the respondent feels secure walking in his/her neighbourhood at night. The question about direct and vicarious victimization is a dichotomy (yes $=1 ; n o=2)$; and the question about fear of crime allows four categories of response from «very safe» to «very unsafe», with higher values indicative of higher degree of fear.

Economic satisfaction. One item asks about the degree of satisfaction with the economic situation of the country. Possible answers are ranked from «completely unsatisfied» $(=0)$ to «completely satisfied» $(=10)$. It is expected that, at least in Spain, questions about the individual situation will be affected by social desirability considerations (Groves et al., 2004). This argument favours enquiring about the country's situation.

Racism (boss and marriage). A battery of two items enquires about whether the respondent would mind that someone from a different race or ethnic group was his/her boss; or married one of his/her close relatives. Items were answerable with an 11-points scale and higher values mean a higher level of concern and, therefore, of racism. There is evidence that values in general (Kury and Obergfell-Fuchs, 2008) and postmodern / postmaterial values in particular (Inglehart, 1997; Inglehart and Welzel, 2005) predict attitudes towards others.

Sociodemographic controls. Age in years; sex (1=male; $2=$ female); political ideology from $0(=\langle$ left») to 10 (=«right»); citizen of country, i.e. whether the respondent had citizenship of the country where he currently lived (1=yes; $2=$ no); being legally married $(=1)$ or in any other situation including «in a legally registered civil union», «legally separated», «legally divorced/civil union dissolved», «widowed/civil partner died» and «none of these» $(=0)$; religiousness, estimated with a question with 11-categories of response about the subjective consideration of being a religious person from «not at all» to «very religious», with higher values indicating that the respondent considers him/herself more religious; size of place of residence, with five categories of response from «a big city» to «farm or home in countryside», with lower values indicating a larger place of residence; education in years; and total household income, with ten categories of response and higher values indicating higher resources. Table 1 shows the descriptive statistics for our dependent, independent and control variables. 
TABLE 1

Descriptive statistics of the variables used in this study

\begin{tabular}{lccccc} 
& N & Min & Max & Mean & St.d. \\
Government should be generous judging...* & 1777 & 1 & 5 & 3,5 & 1,04 \\
Institutional trust & 1582 & $-1,84$ & 3,322 &, 05 &, 997 \\
People with whom you can discuss & 1914 & 0 & 6 & 3,08 & 1,416 \\
How often socially meet & 1927 & 1 & 7 & 5,22 & 1,499 \\
TV watching (general) & 1929 & 0 & 7 & 4,08 & 2,021 \\
TV watching (news) & 1867 & 0 & 7 & 2,19 & 1,546 \\
Satisfied with state of economy & 1914 & 0 & 10 & 2,89 & 2,186 \\
Victimization & 1926 & 1 & 2 & 1,74 &, 439 \\
Fear of crime & 1914 & 1 & 4 & 1,87 &, 771 \\
Most people can be trusted & 1927 & 0 & 10 & 4,83 & 2,127 \\
Racism boss & 1864 & 0 & 10 & 1,88 & 2,801 \\
Racism marriage & 1834 & 0 & 10 & 2,39 & 3,106 \\
Age & 1931 & 15 & 101 & 48,54 & 18,647 \\
Sex & 1931 & 1 & 2 & 1,49 &, 5 \\
Political ideology & 1665 & 0 & 10 & 4,42 & 2,095 \\
Citizen of country & 1931 & 1 & 2 & 1,06 &, 23 \\
Legally married & 1900 & 0 & 1 &, 54 &, 499 \\
Religiousness & 1924 & 0 & 10 & 4,15 & 2,941 \\
Size of place of residence & 1927 & 1 & 5 & 3,06 & 1,148 \\
Education & 1877 & 0 & 45 & 12,73 & 5,756 \\
Household income & 1525 & 1 & 10 & 4,9 & 2,686 \\
\hline
\end{tabular}

*Dependent variable: «Government should be generous judging applications for refugee status». Original responses recoded.

\section{FINDINGS}

It is possible to explore empirically our first hypothesis about the effect of generalized trust in attitudes towards refugees with data from Spain. Table 2 presents the results from three ordinary least squares (OLS) regressions predicting attitudes towards refugees. In the first model, we include independent variables that depend on experience, including institutional trust, people with whom you can discuss and how often socially meet. We include in Model 2 independent variables that do not depend on experience, i.e. generalized trust estimated with a single item (Most people can be trusted) and two 
estimations of racism. The third is the full model. All three models control for age, sex, political ideology, being legally married, holding citizenship of the country of residence, religiousness, size of place of residence, education, household income and country. I will describe the results of three statistical analysis.

TABLE 2

Three OLS regressions predicting attitudes towards refugees in Spain

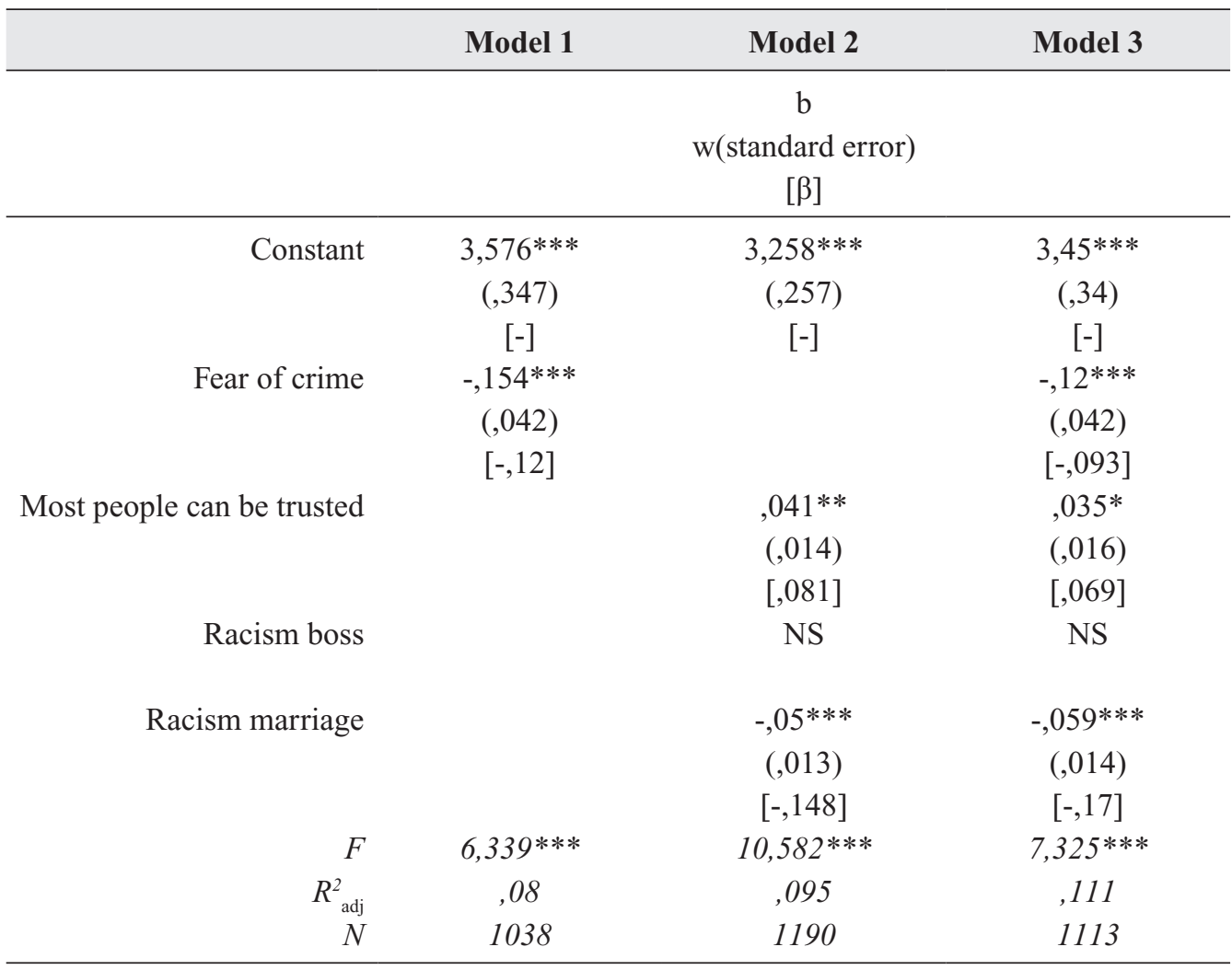

NS: not significant; *:p<0,05; *:p<0,01; ${ }^{*}: \mathrm{p}<0,0005$.

Additional independent variables in $\mathrm{M}_{1}$ and $\mathrm{M}_{3}$ (not shown): Institutional trust, People with whom you can discuss, How often socially meet, TV watching (general), TV watching (news), Satisfied with state of economy and Victimization (in all instances, not significant).

Variables controlled: age, sex, political ideology, citizen of country, legally married, religiousness, size of place of residence, education and household income.

Design weights on.

Fear of crime is the only independent variable predicting attitudes toward refugees at the level alpha $=0,05$ in the first equation. The model shows that the higher the fear of 
crime, the more negative the attitudes towards refugees. Regarding the controls, those who are more conservative, younger, are not legally married, live in smaller towns, are regular citizens and are less educated tend to hold more negative attitudes towards refugees. Political ideology, age and education have the strongest effect in the model, with betas over 0,10 (not shown). Model 1 explains 8 per cent of the variance of the independent variable, a percentage that improves that of a model including only the controls (not shown) $\left(\mathrm{F}=8,665 ; \mathrm{p}<0,0005 ; \mathrm{R}_{\mathrm{ADJ}}^{2}=0,064 ; \mathrm{N}=1225\right)$.

Model 2 includes as independent variables generalized trust and the two versions of racism. According to Uslaner's theory, these variables have a moral basis that is crucial for social life. Generalized trust and the estimation of racism in relation to marriage of a close relative predict attitudes towards refugees in the sense expected by the theory: individuals who are more inclined to think that most people can be trusted and who are less racist show as well more favourable attitudes. This estimation of racism (marriage) has the strongest effect in the model. Model 2 explains 9,5 per cent of the variance of the attitudes towards refugees. Concerning the controls, those who are more conservative, younger, live in smaller towns, have higher household income and are less educated tend to hold more negative attitudes towards refugees. According to goodness of fit statistics, $\mathrm{M}_{2}$ is superior to Model 1, as expected by Uslaner's theory. This evidence supports our second hypothesis $\left(\mathrm{H}_{2}\right)$.

Finally, in the complete model, generalized trust, fear of crime and one of the versions of racism (marriage) are predictors of attitudes towards refugees. What about the controls? Those who are more conservative, younger, are not legally married, live in smaller towns and are less educated tend to hold more negative attitudes towards refugees. Though generalized trust is far from showing the highest standardized coefficients in the model, its effect is not reduced in comparison to the reduced models 1 and 2. For example, $\mathrm{z}$ for the change of the unstandardized coefficients of generalized trust from model 2 to model 3 is just 0,333, below the 1,96 thresholds (Paternoster et al., 1998). This means that the effect of both variables is robust and is not affected by the inclusion of additional independent variables. Model 3 shows the best fit of all three equations and explains 11,1 per cent of the variance ${ }^{2}$.

${ }^{2}$ Some assumptions of the ordinary least squares model seem to have been violated, though they have no impact regarding our hypothesis. 


\section{CONCLUSIONS}

We have found in our present work evidence favourable to a relationship between generalized trust and attitudes towards refugees $\left(\mathrm{H}_{1}\right)$. Though many studies have reported the effect of trust on attitudes towards immigrants, refugees are only one class of immigrants. Immigrants certainly form a heterogeneous category of individuals. At the same time, our results show that trust is far from being a single construct. Institutional trust or trust on institutions such as the country's Parliament, legal system, politicians, political parties, the police or the European Parliament; ingroup trust or trust in individuals like ourselves; and generalized trust or trust in individual different from ourselves are different dimensions or kinds of trust.

Uslaner suggests that generalized trust is established early in life and remains relatively constant therefore. He goes on to put forward the bold argument that attitudes towards strangers depend more on early socialization than on later experience. Our independent variables have been assorted following that logic in our first two models: controlling for a host of controls, independent variables conditional on experience have been included in Model 1 and independent variables unrelated to experience as generalized trust and racist values are included in Model 2. The coefficient of determination corrected for the degrees of freedom confirms that, as predicted by Uslaner, Model 2 explains attitudes towards refugees significantly better than Model 1. In other words, variables that depend on experience predict attitudes towards refugees better than their experience influenced counterparts $\left(\mathrm{H}_{2}\right)$.

Regarding the rest of independent variables, neither TV watching in its two versions of general TV and news or satisfaction with state of economy predict attitudes towards refugees. These null findings are contrary to hypotheses such as economic competition (Mayda, 2006), insecurity (Garland, 2001) or mass media distortion (Kury and Ferdinand, 1999; Stoop, 2007) that have been proposed in similar contexts.

The understanding of morality in the sense of whether an action is right or wrong in an unconditional way has received little explicit attention in social sciences (Andersen, 1990). Guyau was among the first to notice that there were two prominent approaches towards morality in social sciences: one of them understood morality in individual terms; and the other in collective terms. In the second tradition, that can be found in Durkheim's The division of labour in society, morality is equated with solidarity. This is the most prevalent position nowadays. Powell (2010) has reviewed five concepts of morality in theoretical Sociology and he reports that they are different versions of morality as a social phenomenon. The early Parsons (1935) promoted an alternative vision of morality, rejecting what he saw as a positivistic reaction against philosophy in social 
sciences. Parsons, though, later followed a different path, combined with some dose of ambiguity. From this point of view, Uslaner's theory might be a promising approach to integrate both visions of morality as an individual and as a social construct.

Regarding policy, our study suggests that factors stablished early in life play an important role in shaping attitudes towards immigrants and refugees. This points to the necessity of implementing early in life programs as countermeasures to the growing xenophobic attitudes that some researchers have identified in ample areas of the continent. This is not to say that programs that try to improve attitudes later in life cannot be efficient, but they might not be enough. Crucially, institutional trust and other experience-dependent attitudes might depend not only on the quality and performance of institutions but on singular, unpredictable events and be very volatile (Boelhouwer, 2016: 14).

One important limitation of this paper must be acknowledged: the question of temporal order that we cannot be addressed with our data. For example, McLaren (2012) suggests that concerns and attitudes towards immigration precede trust in politicians and political institutions and a similar argument could be made regarding generalized trust, i.e. having more positive attitudes towards immigrants and refugees might be temporally prior to trusting people one does not know.

\section{REFERENCES}

Allport, G.W. (1979). The nature of prejudice, $25^{\text {th }}$. Anniversary edition. Addison-Mesley, Reading, Mass.

Anderson, H. (1990). Morality in three social theories: Parsons, analytical Marxism and Habermas. Acta Sociologica, 33, 4, 321-339.

Andreescu, V. (2011). Attitudes toward immigrants and immigration policy in United Kingdom. Journal of Identity and Migration Studies, 5, 61-85.

Blalock, H.M. (1967). Toward a theory of minority-group relations. John Wiley and Sons, New York.

Boelhouwer, J. (2016). The mood in Europe: opinions on democracy, trust, migrants and life satisfaction. In: Boelhouwer J et al. (eds), Trust, life satisfaction and opinions on immigration in 15 European countries. The Netherlands Institute for Social Research, The Hague, 10-27.

Burns, P. and Gimpel, J. (2000). Economic insecurity, prejudicial stereotypes, and public opinion on immigration policy. Political Science Quarterly, 115(2), 201-225. 
Crepaz, M. M. L., Polk, J. T. , Bakker R. S. and Singh, S.P. (2014). Trust matters: the impact of ingroup and outgroup trust on nativism and civicness. Social Science Quarterly, 95(4), 938-959.

Economidou, C., Karamanis, D., Kechrinioti, A. and Xesfingi, S. (2017). What shapes Europeans' attitudes toward xeno-philia(/phobia)? MPRA Paper no. 76511. Online at https://mpra.ub.uni-muenchen.de/76511/

European Commission (2015). Public opinion in the European Union. Standard Eurobarometer 83. Spring 2015.

European Commission against Racism and Intolerance (ECRI) (2015) Annual Report. Council of Europe, Strasbourg.

Ford, R. (2011) Acceptable and unacceptable immigrants: How opposition to immigration in Britain is affected by migrant's region of origin. Journal of Ethnic and Migration Studies, 37(7), 1017-1037.

Fukuyama, F. (1995). Trust: The social virtues and the creation of prosperity. Hamish Hamilton, London.

Garland, D. (2001). The culture of control. Crime and social order in contemporary society. The University of Chicago Press, Chicago and London.

Greene, W. H. (2012). Econometric analysis, 7. ${ }^{a}$ ed. Pearson, Boston, Mass.

Groves, R. M., Fowler, F. J., Couper, M. P., Lepkowski J M, Singer E and Tourangeau R (2004) Survey methodology. John Wiley and sons, Hoboken, NJ.

Hainmueller, J. and Hangartner, D. (2013). Who gets a Swiss passport? A natural experiment in immigrant discrimination. American Political Science Review, 107, 159-187.

Hainmueller, J. and Hiscox, M. (2010). Attitudes toward highly skilled and low skilled immigration: Evidence from a survey experiment. American Political Science Review, 104, 61-84.

Hainmueller, J. and Hopkins, D. J. (2014). Public attitudes toward immigration. Annual Review of Political Science, 17, 225-249.

Halapuu, V. Paas, T., Tammaru, T. and Schütz A. (2013). Is institutional trust related to pro-immigrant attitudes? A pan-European evidence. Eurasian Geography and Economics, 54(5-6), 572-593.

Heath, A. and Richards, L. (2016). Attitudes towards immigration and their antecedents: topline results from Round 7 of the European Social Survey. European Social Survey ERIC, London.

Herreros, F. and Criado, H. (2009). Social trust, social capital and perceptions of immigration. Political Studies, 57, 337-355.

Inglehart, R. (1997). Modernization and postmodernization. Cultural, economic, and political change in 43 societies. Princeton University Press, Princeton, NY. 
Inglehart, R. and Welzel, C. (2005). Modernization, cultural change, and democracy. The human development sequence. Cambridge University Press, Cambridge.

Kaufmann, E. and Harris, G. (2015). Diversity and attitudes to immigration in Britain. Comparative Political Studies, 50(1), 10-20.

Kury, H. and Ferdinand, T. (1999). Public opinion and punitivity. International Journal of Law and Psychiatry, 22, 373-392.

Kury, H. and Obergfell-Fuchs, J. (2008). Punitivity in Germany: attitudes to punishment, sentencing and prison rates. In: Kury H, Ferdinand T N (eds.), International perspectives on punitivity. Dr. N. Brockmeyer, Bochum, 107-138.

Mayda, A. M. (2006). Who is against immigration? A cross-country investigation of individual attituded toward immigrants. Review of Economics and Statistics, 88(3), 510-530.

Meuleman, R., Lubbers M., and Kraaykamp, G. (2016). Opinions on migration in a European perspective. Trends and differences. In: Boelhouwer J et al. (eds), Trust, life satisfaction and opinions on immigration in 15 European countries. The Netherlands Institute for Social Research, The Hague, 28-53.

McLaren, L. (2003). Anti-immigrant prejudice in Europe: contact, threat perception, and preferences for the exclusion of migrants. Social Forces, 81(3), 909-936.

McLaren, L. (2012). Immigration and trust in Politics in Britain. British Journal of Political Science, 21(1), 163-185.

Parsons, T. (1935). The place of ultimate values in sociological theory. International Journal of Ethics, 45, 3, 282-316.

Powell, C. (2010). Four concepts of morality. Differing epistemic strategies in the classical tradition. In: Hitlin S and Vaisey S (eds), Handbook of the Sociology of morality. Springer, New York, 35-56.

Putnam, R. D. (1995). Bowling alone: America's declining social capital. Journal of Democracy, 6(1), 65-78.

Putnam, R.D. (2001). Bowling alone. The collapse and revival of American community. Simon and Schuster, New York.

Paternoster, R., Brame, R., Mazerolle, P., and Piquero, A. (1998). Using the correct statistical test for the equality of regression coefficients. Criminology, 36(4), 859-866.

Quillian, L. (1995). Prejudice as a response to perceived group threat: population composition and anti-immigrant and racial prejudice in Europe. American Sociological Review, 60(4), 586-611.

Reeskens, T. and Hooghe, M. (2008). Cross-cultural measurement equivalence of generalized trust: evidence from the European Social Survey. Social Indicators Research, 85(3), 515-532. 
Reines, T., Goodwin, M. and Cutts, D. (2017). The future of Europe. Comparing public and elite attitudes. The Royal Institute of International Affairs, London.

Rosenberg, M. (1956) Misanthropy and political ideology. American Sociological Review, 21, 6, 690-695.

Salamonska, J. (2016) Friend or foe? Attitudes towards immigration from other European Union countries. SocietáMutamentoPolitica, 7(13), 237-253.

Serrano-Maíllo, A., Serrano-Tárraga, M.D., and Vázquez González, C. (2008). Un estudio descriptivo y exploratorio de una muestra de delincuentes juveniles nacionales e inmigrantes de segunda nueva generación. In: Serrano-Maíllo, A. (ed), Intersecciones teóricas en Criminología. Acción, elección racional y teoría etiológica. Dykinson, Madrid, 173-230.

Stoop, I. (2007) If it bleads, it leads: the impact of media-reported events. In: Jowell R et al. (eds), Measuring attitudes across-nationality. Sage, London, 95-111.

Thornberry, T. P. and Krohn, M. D. (2000). The self-report method for measuring delinquency and crime. In: Duffee, D. (ed), Criminal Justice 2000, 4. NIJ, Washington, DC, 33-83.

Toshkov, D. and Kortenska, E. (2015). Does immigration undermine public support for integration in the European Union? Journal of Common Market Studies, 53(4), 910925.

Uslaner, E. M. (2002). The moral foundations of trust. Cambridge: Cambridge University Press.

Valentova, M. and Bezosa, G. (2012). Attitudes toward immigrants in Luxemburg. Do contacts matter? International Review of Sociology, 22, 341-363.

Welzel, C. (2013). Freedom rising. Human empowerment and the quest for emancipation. Cambridge University Press, New York.

Wollebaeck, D., Lundasen, S. W. and Trägardh, L. (2012). Three forms of interpersonal trust: evidence from Swedish Municipalities. Scandinavian Political Studies, 35, 319-346. 